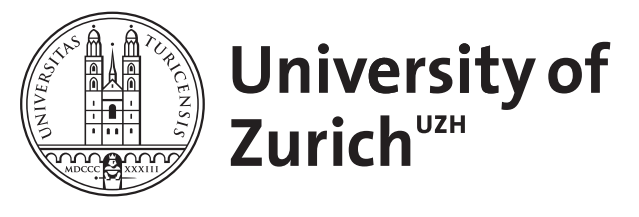

\title{
Regulation of phosphate transport in proximal tubules
}

Biber, J ; Hernando, N ; Forster, I ; Murer, H

\begin{abstract}
Homeostasis of inorganic phosphate $(\mathrm{P}(\mathrm{i}))$ is primarily an affair of the kidneys. Reabsorption of the bulk of filtered $\mathrm{P}(\mathrm{i})$ occurs along the renal proximal tubule and is initiated by apically localized $\mathrm{Na}(+)$-dependent $\mathrm{P}(\mathrm{i})$ cotransporters. Tubular $\mathrm{P}(\mathrm{i})$ reabsorption and therefore renal excretion of $\mathrm{P}(\mathrm{i})$ is controlled by a number of hormones, including phosphatonins, and metabolic factors. In most cases, regulation of $\mathrm{P}(\mathrm{i})$ reabsorption is achieved by changing the apical abundance of $\mathrm{Na}(+) / \mathrm{Pi}$ cotransporters. The regulatory mechanisms involve various signaling pathways and a number of proteins that interact with $\mathrm{Na}(+) / \mathrm{P}(\mathrm{i})$ cotransporters.
\end{abstract}

DOI: https://doi.org/10.1007/s00424-008-0580-8

Posted at the Zurich Open Repository and Archive, University of Zurich ZORA URL: https://doi.org/10.5167/uzh-3960

Journal Article

Published Version

Originally published at:

Biber, J; Hernando, N; Forster, I; Murer, H (2009). Regulation of phosphate transport in proximal tubules. Pflügers Archiv: European Journal of Physiology (Pflugers Archiv), 458(1):39-52.

DOI: https://doi.org/10.1007/s00424-008-0580-8 


\title{
Regulation of phosphate transport in proximal tubules
}

\author{
J. Biber • N. Hernando $\cdot$ I. Forster $\cdot$ H. Murer
}

Received: 30 May 2008 / Accepted: 13 August 2008 / Published online: 29 August 2008

(C) Springer-Verlag 2008

\begin{abstract}
Homeostasis of inorganic phosphate $\left(\mathrm{P}_{\mathrm{i}}\right)$ is primarily an affair of the kidneys. Reabsorption of the bulk of filtered $\mathrm{P}_{\mathrm{i}}$ occurs along the renal proximal tubule and is initiated by apically localized $\mathrm{Na}^{+}$-dependent $\mathrm{P}_{\mathrm{i}}$ cotransporters. Tubular $P_{i}$ reabsorption and therefore renal excretion of $\mathrm{P}_{\mathrm{i}}$ is controlled by a number of hormones, including phosphatonins, and metabolic factors. In most cases, regulation of $\mathrm{P}_{\mathrm{i}}$ reabsorption is achieved by changing the apical abundance of $\mathrm{Na}^{+} / \mathrm{Pi}$ cotransporters. The regulatory mechanisms involve various signaling pathways and a number of proteins that interact with $\mathrm{Na}^{+} / \mathrm{P}_{\mathrm{i}}$ cotransporters.
\end{abstract}

Keywords Sodium-dependent cotransport .

Phosphate homeostasis $\cdot$ Regulation $\cdot$ Phosphate excretion

\section{Introduction}

If one considers the diversity of biological functions of inorganic phosphate $\left(\mathrm{P}_{\mathrm{i}},\right)$ it should come as no surprise that an organism requires mechanisms to maintain the extracellular $\mathrm{P}_{\mathrm{i}}$ reasonably constant. Deviations of the extracellular concentration of $P_{i}$ will impair a variety of physiological processes such as bone metabolism, cellular energetics, protein synthesis, and signaling cascades. In humans, both hypo- and hyperphosphatemia have severe clinical con-

J. Biber $\cdot$ N. Hernando $\cdot$ I. Forster $\cdot$ H. Murer Institute of Physiology and Zurich Center for Integrative Human Physiology, University of Zurich,

Zurich, Switzerland

\section{J. Biber $(\square)$}

Institute of Physiology, University of Zurich,

Winterthurerstrasse 190,

CH-8057 Zurich, Switzerland

e-mail: JuergBiber@access.uzh.ch sequences that underscore the need for stable and wellmanaged $\mathrm{P}_{\mathrm{i}}$ homeostasis [51, 62].

In mammals, including humans, plasma concentration of $P_{i}$ is determined by the intestinal intake of $P_{i}$, the excretion of $P_{i}$ via the feces, the release of $P_{i}$ from bone and soft tissue, and the renal excretion of $P_{i}$. It is the latter mechanism that is of greatest importance for whole body homeostasis of $\mathrm{P}_{\mathrm{i}}$ and therefore needs to be tightly controlled. In quantitative terms, human kidneys filter approximately $200 \mathrm{mmol}$ (or $\sim 20 \mathrm{~g}$ ) of $\mathrm{P}_{\mathrm{i}}$ per day. In the steady state, approximately $15 \%$ or $30 \mathrm{mmol}(\sim 3 \mathrm{~g}) \mathrm{P}_{\mathrm{i}}$ of the filtered load is excreted by the kidneys. Under physiological equilibrium conditions, the total daily renal and fecal $P_{i}$ excretion is approximately equal to the amount of intestinally absorbed $\mathrm{P}_{\mathrm{i}}$ for a normal diet. However, renal excretion of $\mathrm{P}_{\mathrm{i}}$ does not always operate at a constant rate, but it is permanently adjusted according to the daily fluctuations of numerous hormones, including the recently described phosphatonins, and metabolic factors [11, 108, 12] (Table 1). This implies that the transporters involved in reabsorbing $\mathrm{P}_{\mathrm{i}}$ in the proximal tubule are subject to regulatory pathways that (in most cases) affect the abundance of apical $\mathrm{Na}^{+} / \mathrm{P}_{i}$ cotransporters [84, 108]. Moreover, growth and age as factors affecting renal $\mathrm{P}_{\mathrm{i}}$ handling must also be considered as potential regulators of $\mathrm{P}_{\mathrm{i}}$ transporters [110].

This review focuses on those $\mathrm{Na}^{+} / \mathrm{P}_{\mathrm{i}}$ cotransporters localized in the apical membrane of proximal tubules that are involved in the renal $P_{i}$ reabsorption and which respond to $P_{i}$ homeostatic regulatory factors. In this context, we will concentrate on the mechanisms that regulate $\mathrm{P}_{\mathrm{i}}$ excretion via modification of apical expression of $\mathrm{Na}^{+} / \mathrm{P}_{\mathrm{i}}$ cotransporters under both normal physiological and pathophysiological conditions. As most of the data comes from studies on rodents, one should exercise caution when extrapolating 
Table 1 Factors affecting proximal tubular phosphate reabsorption

\begin{tabular}{ll}
\hline Reabsorption decreased by & Reabsorption increased by \\
\hline $\begin{array}{l}\text { Parathyroid hormone } \\
\text { Dopamine }\end{array}$ & $\begin{array}{l}\text { Growth hormone } \\
\text { Insulin-like growth factor } \\
\text { Phosphatonins (FGF-23; } \\
\text { sFRP-4; MEPE) }\end{array}$ \\
$\begin{array}{l}\text { Glucocorticoids } \\
\text { Atrial Natriuretic Peptide }\end{array}$ & Phosphate depletion \\
Phosphate loading & \\
Metabolic acidosis & \\
Carbonic anhydrase inhibitors & \\
Estrogen &
\end{tabular}

the conclusions to higher mammals, including humans. For more integrated views of whole body $\mathrm{P}_{\mathrm{i}}$ homeostasis and specific details of genetic and acquired diseases that impair renal $\mathrm{P}_{\mathrm{i}}$ handling, the reader should refer to the following articles $[14,17,55,70,91,108,113,117,126]$.

\section{Localization and composition of the renal machinery for $P_{i}$ reabsorption}

The $P_{i}$ concentration in the glomerular ultrafiltrate is approximately equal to that in the plasma. Under normal physiological conditions, approximately $80 \%$ of $\mathrm{P}_{\mathrm{i}}$ contained in the primary urine is reabsorbed unidirectionally along the proximal tubules. The amount of $\mathrm{P}_{i}$ reabsorbed in proximal convoluted tubules is up to threefold higher than that in proximal straight tubules. There is no evidence for reabsorption of $\mathrm{P}_{\mathrm{i}}$ along the loop of Henle, but some $\mathrm{P}_{\mathrm{i}}$ may be absorbed along distal tubular segments; however, the identity of the distal tubular transporters is unknown. Moreover, it is unclear if $\mathrm{P}_{\mathrm{i}}$ handling in the distal nephron is relevant for the systemic control of $\mathrm{P}_{\mathrm{i}}$ [for review see, 11, 108].

Uptake of $\mathrm{P}_{\mathrm{i}}$ at the brush border membrane of proximal tubular cells is strictly dependent on the presence of $\mathrm{Na}^{+}$ ions [121], which indicates that there is no paracellular transport of $\mathrm{P}_{\mathrm{i}}$ via cell-cell contact sites. Indeed, all $\mathrm{P}_{\mathrm{i}}$ transporter proteins identified so far and that are localized at the brush border membrane of proximal tubule cells are $\mathrm{Na}^{+}$-dependent. They mediate secondary-active transport by coupling to the free energy of the transmembrane $\mathrm{Na}^{+}$ gradient that is maintained by the $\mathrm{Na}^{+} / \mathrm{K}^{+}$-ATPase localized at the basolateral membrane (Fig. 1). In theory, this would allow sufficient accumulation of $\mathrm{P}_{\mathrm{i}}$ within the cell to provide the driving force for the exit $\operatorname{step}(s)$ of $P_{i}$ at the basolateral side. No detailed information is currently available about the intracellular concentration of free $P_{i}$ or the molecular identity of $\mathrm{P}_{\mathrm{i}}$ transporters localized at the basolateral membrane.
It has been established that $\mathrm{Na}^{+} / \mathrm{P}_{\mathrm{i}}$ cotransport through the brush border membrane is mediated chiefly by gene products of the solute carrier family SLC34 [83]; designated SLC34A1 (NaPi-lla) and SLC34A3 (NaPi-llc). Both SLC34A1 and SLC34A3 are localized at the brush border membrane of proximal tubule cells and have not been detected in other segments of the nephron [32, 99]. Under normal dietary conditions, these proteins are most abundant in S1 segments of both cortical and juxtamedually nephrons, with the highest abundance in the latter. In contrast to NaPi-lla, which gradually decreases along the entire length of the proximal tubule, NaPi-llc has not been detected in the S3 segments of rat and mouse kidneys (Fig. 1) [32, 90].

A gene product of the solute carrier family 17 (SLC17A1 or NaPi-1) was identified based on $\mathrm{Na}^{+} / \mathrm{P}_{i}$ cotransport in an expression cloning study using Xenopus laevis oocytes and was also localized to the brush border membranes of proximal tubules [33]. However, follow-up studies indicated that this cotransporter is most likely not involved in proximal tubular reabsorption of $\mathrm{P}_{\mathrm{i}}$, but rather in the transport of organic ions [21].

Finally, recent findings indicate that a gene product of the solute carrier family 20 (SLC20A2 or PiT-2) [29]) should also be considered as a potential candidate for proximal tubular $\mathrm{P}_{\mathrm{i}}$ reabsorption, as this protein was localized exclusively at the brush border membrane of
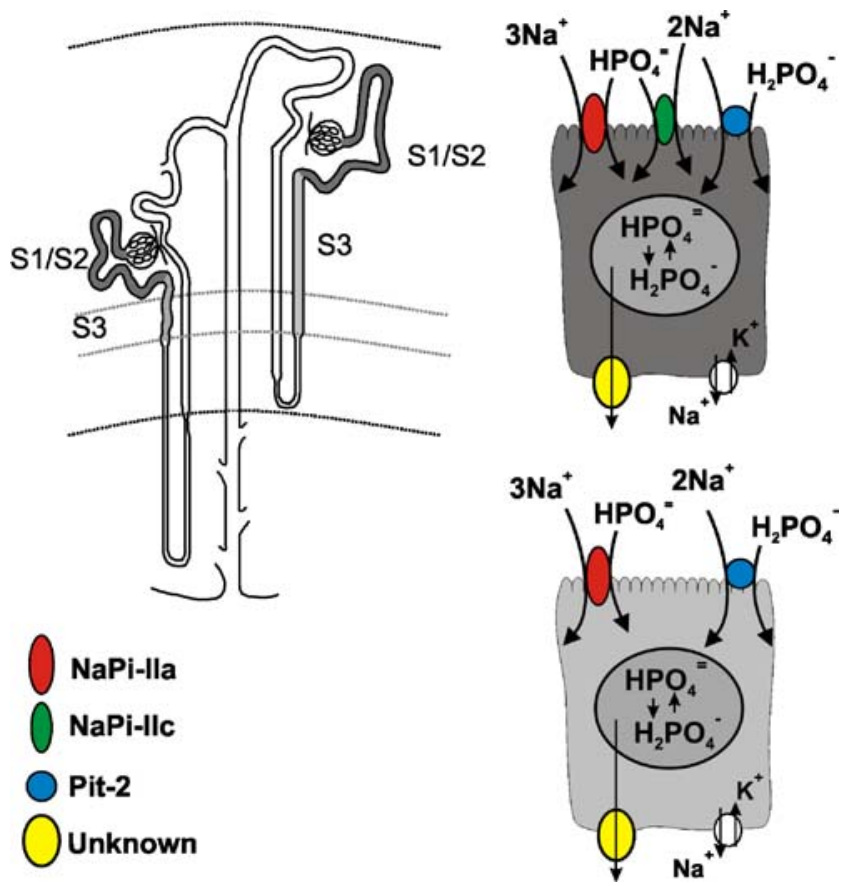

Fig. 1 The renal $\mathrm{P}_{\mathrm{i}}$-reabsorption machinery in rat and mouse proximal tubules. $\mathrm{Na}^{+} / \mathrm{P}_{\mathrm{i}}$-cotransporters $\mathrm{NaPi}-1 \mathrm{lla}, \mathrm{NaPi}-1 \mathrm{lc}$ and $\mathrm{Pit}-2$ are localized at the brush borders of proximal tubules. NaPi-lla and Pit-2 proteins are detected in S1, S2 and S3 segments, whereas NaPillc cotransporter is absent in $\mathrm{S} 3$ segments 
proximal tubules (Villa-Bellosta R, Ravera S, et al., unpublished observations). Its contribution to proximal tubule $\mathrm{P}_{\mathrm{i}}$ reabsorption and significance for whole body $\mathrm{P}_{\mathrm{i}}$ homeostasis remain to be determined.

\section{How do different $\mathrm{Na}^{+} / \mathbf{P}_{i}$ cotransporters contribute to renal $P_{i}$ reabsorption?}

Recent studies indicate that to answer this question, we must take account of the species and developmental stage of the animals under investigation. Furthermore, the finding that NaPi-lla, NaPi-llc, and Pit-2 show different time courses of dietary or hormonal regulation suggests that the underlying signaling pathways differ.

Knockout of the gene encoding NaPi-lla (Npt2) established that in adult mice, $\mathrm{P}_{\mathrm{i}}$ reabsorption is mediated largely by $\mathrm{NaPi}-1 \mathrm{la}$ [7]. In brush border membrane vesicles (BBMV's) isolated from $\mathrm{Npt}^{-/-}$mice, $\mathrm{Na}^{+}$-dependent $\mathrm{P}_{\mathrm{i}}$ uptake was reduced by $70 \%$, which could account for the observed hypophosphatemic state of these animals. The remaining $30 \%$ of $\mathrm{Na}^{+} / \mathrm{P}_{\mathrm{i}}$ cotransport in BBMV's has been attributed to the activity of NaPi-llc as its abundance increased in $\mathrm{Npt}^{-/-}$mice [115]. Taken together, these observations suggested that in adult wild-type mice, $\mathrm{Na}^{+} / \mathrm{P}_{\mathrm{i}}$ cotransport via $\mathrm{NaPi}$-llc plays only a marginal role. In agreement, $\mathrm{NaPi}-$ llc abundance was found to be highest in weaning mice and decreased with age [99]. This conclusion is further supported by the lack of a phenotype in $\mathrm{NaPi}-11 \mathrm{c}^{-/-}$mice [79].

In humans, particularly adults, the contribution of the $\mathrm{NaPi}$-IIc to renal reabsorption of $\mathrm{P}_{\mathrm{i}}$ and to whole body $\mathrm{P}_{\mathrm{i}}$ homeostasis appears to be more important than in mice. Mutations in the SLC34A3 gene have been described in patients with hereditary hypophosphatemic rickets with hypercalcuria (HHRH) by two independent studies [9, 75]. The renal wasting of $\mathrm{P}_{\mathrm{i}}$ associated with this disease can therefore be correlated with an impaired function of NaPillc. This suggests that in adult humans, NaPi-llc contributes significantly to renal $\mathrm{P}_{\mathrm{i}}$ reabsorption under normal steadystate conditions.

On the basis of in situ hybridization, expression of both members of the SLC20 family [29], Pit-1 and Pit-2, was detected along the entire nephron [116]. As noted above, the Pit-2 protein was recently localized in the brush border membranes of proximal tubules (Villa-Bellosta R, Ravera S et al., unpublished observations), but its contribution to renal $\mathrm{P}_{\mathrm{i}}$ reabsorption remains unknown.

\section{$\mathrm{Na}^{+} / \mathbf{P}_{\mathrm{i}}$ cotransporters at work}

The transport kinetics of NaPi-lla, NaPi-llc, and Pit-1, -2 have been characterized in detail using the Xenopus laevis oocyte expression system [for review see 38, 124]. All four proteins prefer $\mathrm{Na}^{+}$ions as the driving substrate, and $\mathrm{P}_{i}$ as the driven substrate, yet there are important differences that could influence their respective physiological functions.

First, NaPi-IIa is electrogenic, whereas NaPi-IIc is electroneutral. This finding is consistent with their different transport stoichiometries. Both prefer divalent $\mathrm{P}_{\mathrm{i}}\left(\mathrm{HPO}_{4}{ }{ }^{\prime}\right)$; $\mathrm{NaPi}-1$ la displays a $\mathrm{Na}^{+}: \mathrm{P}_{\mathrm{i}}$ stoichiometry of $3: 1$, whereas for $\mathrm{NaPi}-1 \mathrm{lc}$, the stoichiometry is 2:1. Thus, the electrogenicity of NaPi-lla arises from the translocation of an additional $\mathrm{Na}^{+}$ion, at greater energetic cost to the cell. Despite this fundamental difference, at neutral $\mathrm{pH}$, both $\mathrm{NaPi}-\mathrm{II} a$ and NaPi-IIc show similar apparent affinities for $\mathrm{Na}^{+}(\sim 50 \mathrm{mM})$ and $\mathrm{P}_{\mathrm{i}}(<0.1 \mathrm{mM})$ as well as a qualitatively similar decreased transport activity with external acidification [38, 124, 125].

Second, in contrast to $\mathrm{NaPi}-\mathrm{IIa} / \mathrm{c}, \mathrm{PiT}-1 / 2$ prefer monovalent $\mathrm{P}_{\mathrm{i}}\left(\mathrm{H}_{2} \mathrm{PO}_{4}{ }^{-}\right)$. Like NaPi-lla, both Pit-1 and Pit-2 are electrogenic, yet Pit-1 has been shown experimentally to display a $2: 1 \mathrm{Na}^{+}: \mathrm{Pi}$ stoichiometry. Apparent affinities for $\mathrm{Na}^{+}$are in the range of 50 to $70 \mathrm{mM}$ and for $\mathrm{P}_{\mathrm{i}} \sim 0.1 \mathrm{mM}$ $[18,93,124]$. Unlike $\mathrm{NaPi}-\mathrm{IIa} / \mathrm{c}, \mathrm{Li}^{+}$can also support $\mathrm{P}_{\mathrm{i}}$ translocation by PiT-1, but at a significantly reduced rate and there is a weak affinity for arsenate [93].

Third, the $\mathrm{pH}$ dependence of NaP-lla and NaPi-llc is similar; transport rates approximately double between pH 6.5 and 8 [124]. Such a pH-dependence may have to be considered when assessing renal excretion of $P_{i}$ under conditions of an altered acid base status of the body $[46,87]$. In contrast, the predicted maximum transport velocity for Pit-1/2-mediated $\mathrm{Na}^{+} / \mathrm{P}_{\mathrm{i}}$ cotransport is quite constant within this $\mathrm{pH}$ range [93].

Finally, until recently, phosphonoformic acid (PFA) was considered a general competitive inhibitor of $\mathrm{Na}^{+} / \mathrm{P}_{\mathrm{i}}$ cotransport [112]. Current data indicate that it inhibits only $\mathrm{Na}^{+} / \mathrm{P}_{i}$ cotransport mediated by SLC34 family gene products. The $\mathrm{K}_{\mathrm{i}}$ for PFA is approximately tenfold higher for PiT-1, -2 compared to that reported for NaPi-IIa. This may be a direct consequence of the different preference for $\mathrm{P}_{\mathrm{i}}$ of the two families as PFA is expected to be divalent under normal physiological conditions [93].

Currently, no information about the three-dimensional structure of $\mathrm{Na}^{+} / \mathrm{P}_{i}$ cotransporters is available. Based on extensive studies using cysteine scanning combined with functional studies and in vitro transcription/translation approaches, SLC34 proteins are predicted to comprise eight transmembrane domains with intracellular $\mathrm{N}$ - and $\mathrm{C}$ termini. A large extracellular loop region links two halves of the protein that contain conserved repeated sequences also found in bacterial homologs. The repeats are proposed to form opposed reentrant loops that most likely constitute the transport pathway [38, 92, 124]. The secondary structure of SLC20 proteins is less well defined: they are 
predicted to comprise ten transmembrane domains with extracellular $\mathrm{N}$ - and $\mathrm{C}$-termini, however evidence for an obvious repeat region is so far lacking, and there is no homology with the SLC34 gene products in the proposed substrate translocation region $[18,98]$.

The functional unit of NaPi-lla is a monomer [63]. Interestingly, a split-ubiquitin yeast two-hybrid assay, and subsequent studies provided evidence that NaPi-lla may homodimerize [42]. Although apparently not relevant for transport function, one can speculate that homotypic interactions of NaPi-lla proteins may be of relevance for the regulation of this cotransporter.

\section{Apical positioning of $\mathrm{Na}^{+} / \mathrm{P}_{\mathrm{i}}$ cotransporters}

After correct targeting and insertion into the plasma membrane of epithelial cells, specific protein-protein interactions may be required to stabilize the final localization of membrane proteins [130]. Classical yeast twohybrid screens performed against the $\mathrm{C}$-terminus of $\mathrm{NaPi}-1 \mathrm{la}$

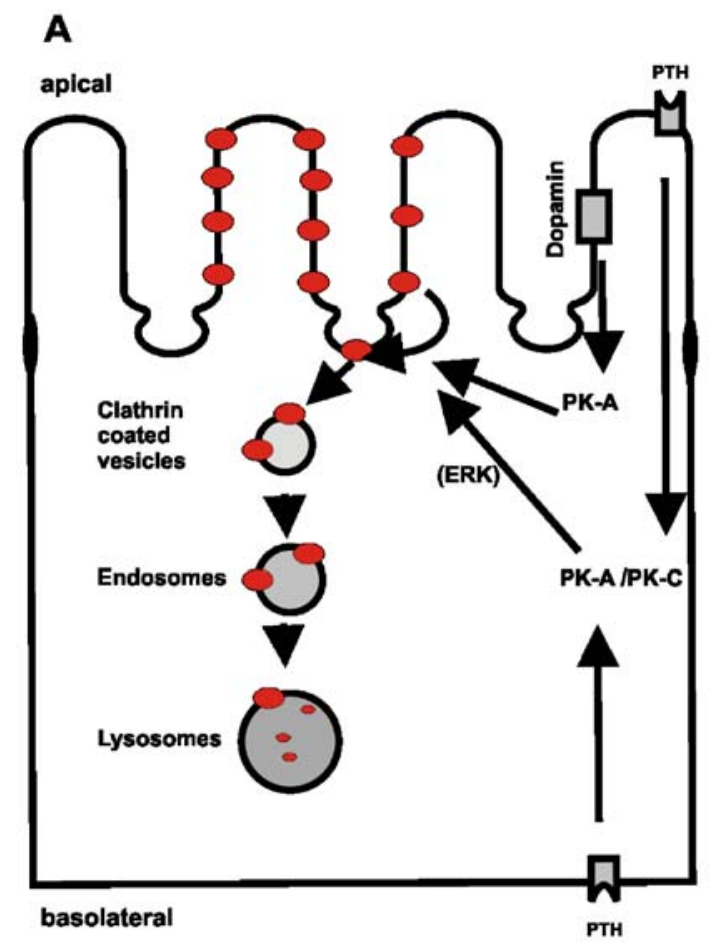

\section{NaPi-lla}

Fig. 2 Regulation of the NaPi-lla Na ${ }^{+} / \mathrm{P}_{\mathrm{i}}$-cotransporter. a Activation of protein kinase dependent signaling pathways, e.g, by PTH or dopamine, provoke internalization of NaPi-lla cotransporters at the intermicrovillar clefts. Internalized NaPi-lla proteins are degraded in the lysosomes. b Schematic illustration of the apical sorting and positioning of NaPi-lla by PDZ proteins [15, 43, 44, 104]. The revealed interactions of this cotransporter with several PDZ domain (PSD-95, discs-large, ZO-1) containing proteins that may contribute to the stabilization of NaPi-lla at the apical membrane (Fig. 2b) [15, 42-44]. Robust interactions of NaPi-lla with single PDZ domains of the sodiumhydrogen exchanger regulatory factor (NHERF), protein family [104], NHERF1 and 2, NHERF3 (PDZK1) and NHERF4 (PDZK2) have been demonstrated in in vitro studies. Members of the NHERF family were proposed to scaffold several other membrane proteins, including transporters and receptors as well [43, 44]. Furthermore, NHERF $1 / 2$ bind to members of the merlin-ezrin-radixinmoesin (MERM) protein family, thereby providing a link to the cytoskeleton [104].

The interactions of NaPi-lla with PDZ domains of the NHERF family were shown to be primarily via a class I PDZ binding motif (TRL) located at the C-terminus [43, 44]. In opossum kidney (OK) cells, the TRL-motif was shown to be required for apical expression [49]. The roles of some of these interactions of NaPi-lla with PDZ proteins have been elucidated using several mouse knockout

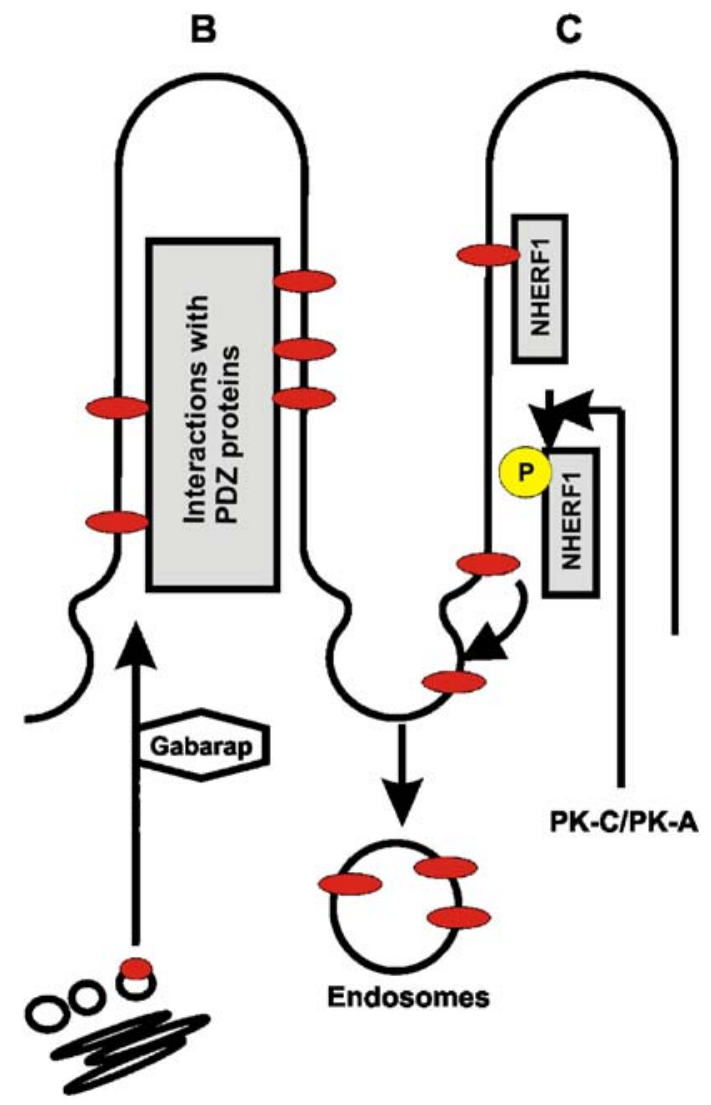

recently suggested role of Gabarap in determining apical abundance of $\mathrm{NaPi}$-lla [94] is also indicated. c Modulation of the interaction of NaPi-lla with NHERF1 by protein kinases activated by PTH. Phosphorylation of NHERF1 [128] weakens the apparent affinity for $\mathrm{NaPi}-1 \mathrm{la}$, which is subsequently delivered to the endocytic machinery 
models. NHERF $1^{-/-}$mice exhibited phosphaturia that could be explained by a decrease of the apical abundance of NaPi-lla [105]. These findings indicate a stabilization effect of NHERF1 on the membrane expression of NaPi-lla. In contrast, in NHERF2 ${ }^{-/-}$mice, urinary excretion of $\mathrm{P}_{\mathrm{i}}$ and apical expression of NaPi-lla were unaffected under normal physiological conditions [31]. Despite the robust in vitro interactions of NaPi-lla with NHERF3, neither urinary excretion of $\mathrm{P}_{\mathrm{i}}$ nor the abundance of NaPi-lla was impaired in NHERF3 ${ }^{-/}$mice [23].

In addition to the NHERF proteins, NaPi-lla also interacts with the PDZ domain of Shank2E, a splice form of Shank2 [78]. Shank2E is localized at the brush border membrane of proximal tubule cells, and there is evidence that it may be involved in the endocytic machinery that determines the surface abundance of NaPi-lla.

A recent study revealed a role for the $\mathrm{GABA}_{\mathrm{A}}$-receptor associated protein (Gabarap) in determining the apical amount of NaPi-lla [94]. In BBMV isolated from Gabarap $^{-1-}$ mice, the amount of NaPi-lla was increased, whereas NaPi-llc was unaffected. In agreement with these findings, $\mathrm{Na}^{+} / \mathrm{P}_{\mathrm{i}}$ cotransport was higher in BBMV's from Gabarap $^{-1}$ animals, which was reflected in a reduced urinary $\mathrm{P}_{\mathrm{i}}$ excretion. The molecular mechanism underlying the action of Gabarap is unknown. Gabarap may exert its effect on he apical sorting as it interacts with the $N$ ethylmaleimide-sensitive factor NSF [61]. Alternatively, NHERF1 which was also up-regulated in Gabarap ${ }^{-/}$mice [94], may increase the stabilization of NaPi-lla in the brush border membrane of these animals.

Currently, there is little information about proteins interacting with $\mathrm{NaPi}$-llc or Pit-2. NaPi-IIc was reported to interact with NHERF1 and NHERF3 [123], the consequences of these interactions for apical positioning and regulation of $\mathrm{NaPi}-\mathrm{llc}$ remain to be clarified.

\section{Regulation of proximal tubular $\mathrm{Na}^{+} / \mathrm{Pi}$ cotransport}

\section{General considerations}

Theoretical considerations predict that at equilibrium, secondary active $\mathrm{Na}^{+} / \mathrm{P}_{\mathrm{i}}$ cotransport across the brush border membrane of proximal tubules would give rise to a concentrating capacity of 100:1 for NaPi-llc and 10,000:1 for NaPi-lla [45, 124]. Although precise values for the intracellular concentration of $\mathrm{P}_{\mathrm{i}}$ are unavailable, it is estimated to be in the lower millimolar range [14]. Thus, for a given membrane protein density, the capacity of proximal epithelia to reabsorb $P_{i}$ is not determined by the driving force but by the turnover rate of the transport cycle. Alteration of $\mathrm{P}_{i}$ reabsorption therefore could be achieved either by changes in the abundance of $\mathrm{Na}^{+} / \mathrm{P}_{\mathrm{i}}$ cotransport- ers, the apparent affinities for the substrates or the lipid composition, which could influence the preferred conformational state of the protein and modulate partial reactions that constitute the transport cycle.

Most of the known effects of hormones and metabolic factors (Table 1) on renal $\mathrm{P}_{\mathrm{i}}$ absorption take place via alterations of the abundance of $\mathrm{Na}^{+} / \mathrm{P}_{\mathrm{i}}$ cotransporters within the proximal brush border membrane. The membrane abundance of a Na $/ \mathrm{P}_{\mathrm{i}}$ cotransporter depends on the rate of protein synthesis in the biosynthetic pathway, the rate of insertion into the apical membrane and the rate of endocytotic processes. Currently, we know more about down-regulation (via endocytosis) of $\mathrm{Na}^{+} / \mathrm{P}_{\mathrm{i}}$ cotransporters (in particular NaPi-lla) than about the possible regulation of the apical sorting and insertion of newly synthesized cotransporters into the brush border membrane. In the following section, we will present an overall picture of the current knowledge about the acute hormonal regulation of $\mathrm{Na}^{+} / \mathrm{P}_{\mathrm{i}}$ cotransporters, such as, e.g., by parathyroid hormone. Other important regulators of apical $\mathrm{Na}^{+} / \mathrm{Pi}$ cotransporter abundance, such as phosphatonins, $\mathrm{P}_{\mathrm{i}}$ diet and steroids are discussed in separate sections. Finally, a few cases in which changes of renal excretion of $\mathrm{Pi}$ do not match alterations of apical abundance of $\mathrm{Na}^{+} / \mathrm{Pi}$ cotransporters will be discussed.

\section{Changes in renal $P_{i}$ excretion related to alterations of $\mathrm{Na}^{+} / \mathbf{P}_{i}$ cotransporter abundance}

\section{Parathyroid hormone}

The paradigm for the alteration of the apical abundance of $\mathrm{Na}^{+} / \mathrm{P}_{\mathrm{i}}$ cotransporters is represented by the regulation of the NaPi-lla protein by parathyroid hormone (PTH) (Fig. 2a). Upon stimulation of PTH receptors, a decrease of apical NaPi-lla abundance occurs within minutes, without changes in mRNA levels [4, 58]. In contrast, several hours are required for a PTH-induced redistribution of NaPi-llc [90, 103]. This indicates that (at least in rodents) acute adjustment of renal $\mathrm{P}_{\mathrm{i}}$ reabsorption by PTH occurs mostly by a redistribution of NaPi-lla. So far, no regulation of Pit-2 by PTH in proximal tubules has been described.

Stimulation of PTH receptors leads to a rapid internalization of NaPi-lla via an endocytotic machinery located at the intermicrovillar clefts that was not associated with fluid phase uptake, but was shown to be mechanistically similar to a receptor-mediated process that involves clathrin-coated vesicles [4]. Although putative endocytic motifs such as tyrosine- or di-leucine-based motifs are contained within the amino acid sequence of NaPi-lla, mutations of these motifs did not affect the retrieval of NaPi-1la [50]. Instead, a dibasic amino acid motif (KR), most likely localized within 
an intracellular loop, was found to be required for internalization and degradation of NaPi-lla [56]. The absence of this KR motif in the NaPi-llc protein could explain the different endocytic rates of the NaPi-lla and NaPi-llc cotransporters after PTH stimulation. It is of interest that the peroxisomal farnesylated protein PEX19 was reported to interact with NaPi-lla via the KR motif, yet the precise role of PEX19 in the trafficking of NaPi-lla has not been elucidated [54].

Unlike megalin [28], internalized NaPi-lla is not delivered to recycling subapical endosomes but, instead, is routed from the early endosomes to the lysosomes where it is degraded [4, 59, 89] (Fig. 2a). No lysosomal association of NaPi-llc was detected after stimulation with PTH [90, 103], which again indicates that any intracellular trafficking of NaPi-llc after hormonal stimulation differs from that of NaPi-lla.

Several observations suggest that the final reaction(s) of the PTH-induced signaling cascades leading to NaPi-IIa endocytosis may affect the affinity of the cotransporter for its interacting proteins. The signaling cascades involved in the action of PTH have been well described. Receptors for PTH are localized both at the apical and the basolateral site of proximal tubular cells and differ with respect to their activation by different PTH fragments and formation of intracellular second messengers [41]. Stimulation of basolateral PTH receptors by 1-34 PTH (via Gs) provokes an increase of the intracellular cAMP concentration and activation of protein kinase A-dependent pathways, whereas stimulation of apical PTH receptors by 1-34 PTH or 3-34 PTH (via Gq) results in the hydrolysis of $\mathrm{PIP}_{2}$ and activation of pathways involving protein kinase $\mathrm{C}$ activity. Experiments performed on isolated rat proximal tubules indicated that stimulation of both, apical and basolateral PTH receptors, elicits a down-regulation of NaPi-lla [119]. Apical PTH receptors are part of a signaling complex scaffolded by NHERF1 that also includes phospholipase PLCB2 [77]. The importance of such a spatial arrangement for the hormonal regulation of the abundance of NaPi-lla was demonstrated in experiments using kidney slices derived from NHERF $1^{-1-}$ mice. The coupling of apical PTH receptors to the down-regulation of NaPi-lla was completely abolished in the absence of NHERF1, whereas down-regulation of NaPi-lla induced by a stimulation of basolateral PTH receptors (via cAMP) remained intact [22].

In addition to PKA and PKC pathways, regulation of the amount of NaPi-lla by a pathway that involves protein kinase $G$ should also be considered. Early studies documented that part of the renal response to the atrial natriuretic factor (ANF) includes changes of $\mathrm{Na}^{+} / \mathrm{P}_{\mathrm{i}}$ cotransport [48]. Later, it was demonstrated that increases of cGMP concentrations induced by ANP or by nitric oxide (NO) resulted in a down-regulation of NaPi-lla [3].
An involvement of MAPK (ERK1/2) kinases in the PTH action has been suggested from experiments performed with opossum kidney (OK) cells [67]. Moreover, in ex vivo studies, using mouse kidney slices, down-regulation of NaPi-lla initiated by 1-34 PTH was partially prevented by the ERK1/2 inhibitor PD098059 [5]. Similarly, downregulation of NaPi-lla was partially inhibited by this blocker when PKC or PKG pathways were pharmacologically activated separately. In contrast, inhibition of ERK1/2 completely abolished endocytosis of NaPi-lla in response to direct activation of PKA [5]. Based on these observations, we can envisage a central role of the MAPK pathway as a point where the different pathways (PKA, PKC, and PKG) may converge (Fig. 2a). Interestingly, inhibition of renal $P_{i}$ reabsorption by $\mathrm{FGF}-23$ (see below) was also reported to involve activation of the MAPK kinase pathway [129].

Is MAPK always required for down-regulation of $\mathrm{NaPi}-$ 1la? Investigations related to the phosphaturic effect of dopamine [39] demonstrated that dopamine elicits a downregulation of NaPi-lla via stimulation of apical dopamine receptors D1 [2]. This D1-receptor-mediated effect on NaPi-lla abundance was completely prevented by a blocker of PKA (H89) but not by inhibiting ERK1/2 MAPK kinases, which indicates that cAMP dependent pathways relevant for down-regulation of NaPi-lla may differ, depending on which receptor is activated (Fig. 2a).

The subcellular location of NHERF proteins remains unaffected after PTH treatment. The implication of different kinases in the signaling cascades described above suggest that the stability of NaPi-IIa within apical heteromultimeric protein complexes, such as the one scaffolded by NHERF1, may be altered by protein phosphorylation. Studies addressing this question revealed that NaPi-lla was not phosphorylated either basally or upon stimulation by PTH [34]. However, increased phosphorylation of NHERF1 in response to PTH has been observed in murine kidney slices and suggested that phosphorylation of NHERF1 could induce a dissociation of the NaPi-lla/NHERF1 complex [34]. Recently, a more detailed study demonstrated that after activation of PKC and PKA pathways, a serine residue (Ser77) within the first PDZ domain of NHERF1 was phosphorylated [128] (Fig. 2c). Phosphorylation of Ser77 upon activation of PKC appeared to occur more directly compared to the PKA effect. Because NaPi-lla interacts with the first PDZ domain of NHERF1 [43, 44] and Ser77 is located within the predicted binding domain, phosphorylation of Ser77 is thought to induce a conformational change resulting in a lowered affinity of the NaPi-lla/ NHERF1 interaction. In this respect, it is interesing to note that truncation of the PDZ binding motif of the CFTR channel increased its diffusional mobility within the membrane [47]. Similarly, by promoting phosphorylation 
of NHERF1, PTH (and possibly other factors) could induce an increase of the mobility of NaPi-lla along the microvillus axis that may be required for internalization at the intermicrovillar clefts.

\section{Phosphatonins}

Tumor-induced osteomalacia (TIO), autosomal-dominant hypo-phosphatemic rickets (ADHR), recessive hyperphosphatemic rickets (ARHR) and X-linked hypophosphatemic rickets $(\mathrm{XLH})$ are associated with phosphaturia and defects in bone metabolism [126]. Associated with these diseases, various new factors, termed phosphatonins, have been identified and were shown to be involved in the observed renal $\mathrm{P}_{\mathrm{i}}$ wasting. So far, the list of phosphatonins comprises fibroblast growth factor 23 (FGF-23), secreted frizzled related protein-4 (sFRP-4), matrix extracellular phosphoglycoprotein (MEPE), and fibroblast growth factor 7 (FGF-7). The roles of phosphatonins in whole body $\mathrm{P}_{\mathrm{i}}$-homeostasis under pathophysiological conditions has recently been reviewed [12, 17, 55, 91, 117, 126]. However, apart from their roles in disease conditions, phosphatonins may exert regulatory functions on renal $\mathrm{P}_{\mathrm{i}}$ reabsorption also under normal physiological conditions, whereby interference by other factors cannot be excluded [97, 106, 107, 109]. Overall, little is known about the signaling pathways of phosphatonins in proximal tubule cells that result in alterations of the abundance of $\mathrm{Na}^{+} / \mathrm{P}_{\mathrm{i}}$ cotransporters. Current knowledge about the cellular mechanisms is briefly discussed below.

Fibroblast growth factor FGF-23 FGF-23 was identified in patients with autosomal dominant hypophosphatemic rickets (ADHR) by positional cloning [30]. The phosphaturic effect observed at elevated serum levels of FGF-23 correlated with a decrease of the abundance of NaPi-lla and NaPi-llc $[79,80]$. Moreover, FGF23 ${ }^{-/}$mice display the converse behavior with increased $\mathrm{P}_{\mathrm{i}}$ reabsorption and hyperphosphatemia [107]. In ex vivo studies, using isolated proximal tubules, FGF-23 was reported to reduce NaPi-lla abundance [6].

FGF-23 likely activates one of the known c-splice isoforms of FGF receptors (FGFR). Some in vitro studies suggested the interaction of FGF-23 with FGFR's 1c, 3c , and 4c; however, the identity of the FGFR responsible for the action of FGF-23 in proximal tubules is currently unknown. FGF-23 receptors belong to the family of receptor tyrosine kinases, and its activation appears to be dependent on the presence of sugar chains such as those contained in heparin or klotho $[65,66,74]$. It is significant that klotho (see below) is required for the conversion of canonical FGFR's into functional FGF-23 receptors [122]. The importance of klotho for FGF-23 action was further suggested from observations made using a $\mathrm{klotho}^{-/-}$mouse model that develops a phenotype similar as $\mathrm{FGF}-23^{-/-}$mice [102]. In klotho $^{-1-}$ mice, the increase of serum $P_{i}$ concentration could be correlated with increased abundances of NaPi-lla and NaPi-llc despite a massive increase of FGF-23 serum levels.

Studies in OK cells provided evidence that the signaling pathway activated by FGF-23 involves MAPK/ERK1-2 kinases [129]. Similarly as described for the PTH-induced signaling pathway (see above), the action of FGF-23 was blocked by inhibitors of ERK1/2. In addition, in isolated proximal tubules, FGF-23 was reported to provoke an increase of the production of prostaglandin PGE2 that was also suggested to occur via the MAPK/ERK pathway [111].

Secreted frizzled-related protein-4 Secreted frizzled-related protein-4 (sFRP-4) is overexpressed in TIO patients presenting renal $\mathrm{P}_{\mathrm{i}}$ wasting [for review see 12]. Infusion of sFRP-4 into rodents was shown to provoke phosphaturia that could be correlated with a decrease of NaPi-lla [10]. sFRP-4 is an antagonist of the Wnt pathway and, indeed, after infusion of sFRP-4, a decrease of the phosphorylated form of $\beta$-catenin was detected. However, the time course and the precise mechanism by which sFRP-4 leads to down-regulation of NaPi-IIa needs to be explored further.

Matrix extracellular phospho-glycoprotein and fibroblast growth factor 7 Overexpression of two other factors matrix extracellular phospho-glycoprotein (MEPE) and FGF-7, has been noted in tumors of TIO patients as well [for review see 12]. MEPE was also identified in tissue from a patient with oncogenic hypophosphatemic osteomalacia [95]. Conflicting results have been reported with respect to a direct action of MEPE on renal $\mathrm{P}_{\mathrm{i}}$ handling. A recent study demonstrated that in rats, infusion of recombinant MEPE elicited an increase of $\mathrm{P}_{\mathrm{i}}$ excretion [35]. Together with data obtained from cell culture experiments [96], it appears that MEPE indeed participates in the control of proximal $\mathrm{P}_{\mathrm{i}}$ reabsorption. However, the precise mechanisms of the action of MEPE are not known. Also, further investigation will be required to establish if other factors regulating $\mathrm{P}_{\mathrm{i}}$ homeostasis also interact with the renal action of MEPE.

Only minimal information is available at present about FGF-7 regarding its role in renal $\mathrm{P}_{\mathrm{i}}$ wasting as observed in TIO patients. Based on studies performed with OK-cells, FGF-7 inhibits $\mathrm{Na}^{+} / \mathrm{P}_{\mathrm{i}}$ cotransport [25].

\section{Klotho}

In addition to interaction with FGF receptors (see above), klotho may exert direct effects on the abundance of $\mathrm{Na}^{+} / \mathrm{P}_{\mathrm{i}}$ cotransporters in proximal tubules. The extracellular domain of klotho, which is anchored by a single transmem- 
brane segment, shows $\sim 40 \%$ homology to B-glycosidase family-1 enzymes and thus may enyzmatically alter sugar moieties of membrane proteins [118]. In kidneys, klotho is expressed in distal convoluted tubules [65]. Interestingly, the extracellular domain of klotho is shed from the membrane and is detected in the blood, which indicates that this domain may act as a humoral factor [53, 65, 85]. Evidence for a direct action of klotho on NaPi-lla abundance was reported from in vitro experiments using microperfused proximal tubules and isolated BBMV's [52]. Most interestingly, incubation of BBMV's with klotho reduced $\mathrm{Na}^{+} / \mathrm{P}_{\mathrm{i}}$ cotransport activity, an effect most likely was due to a change in the glycosylation of NaPi-lla itself. These observations suggest that modification of the glycosylation moieties of NaPi-lla may affect its apical stability, similar to that described for the calcium channel TRPV5 [27].

\section{Dietary $\mathrm{P}_{\mathrm{i}}$ intake}

It has long been known that changes in the dietary intake of $\mathrm{P}_{\mathrm{i}}$ affect renal excretion of $\mathrm{P}_{\mathrm{i}}$. Interestingly, the capacity of renal $P_{i}$ reabsorption adapts to altered intake of $P_{i}$ within less than an hour (acute adaptation) and remains adjusted during prolonged intake of dietary $\mathrm{P}_{\mathrm{i}}$ (chronic adaptation) $[71,73]$.

Adaptation to altered $\mathrm{P}_{\mathrm{i}}$ diet is independent of $\mathrm{PTH}$, vitamin D3, and growth hormones [19, 24, 71, 120]. However, analysis of the mechanisms involved in such dietary adaptation can be complicated by the involvement of other factors. For example, serum levels of FGF-23 were reported to be dependent on the state of phosphatemia [127]. Furthermore, studies performed with diabetic rats indicated that insulin may have a permissive effect on the adaptive response to low $\mathrm{P}_{\mathrm{i}}$ diet as the increase of apical $\mathrm{Na}^{+} / \mathrm{P}_{i}$ cotransport was abolished in these rats [1]. Also, lowered plasma levels of $P_{i}$ may affect the rates of metabolic pathways of proximal tubular cells, such as for example of gluconeogenesis [64].

Within the first four hours after ingestion of a low $\mathrm{P}_{\mathrm{i}}$ diet, brush border $\mathrm{Na}^{+} / \mathrm{P}_{\mathrm{i}}$ cotransport increases due to an increase of the amount of NaPi-lla [26, 71, 73]. Rapid upregulation induced by low $\mathrm{P}_{\mathrm{i}}$ diet was also observed for Pit2 but not for NaPi-llc [79 and Ravera S et al., unpublished observations]. Whereas acute changes of NaPi-IIa abundance are independent of transcriptional regulation, controversial findings regarding the chronic regulation have been reported. In weaning mice, a chronic low $\mathrm{P}_{\mathrm{i}}$ diet elevates the amount of NaPi-lla mRNA in addition to protein abundance. This effect was ascribed to a $P_{i}$ responsive element located within the promoter region of the Npt2 gene [60]. However, in adult mice fed chronically with a low $\mathrm{P}_{\mathrm{i}}$ diet an increase of NaPi-llc mRNA but not of NaPilla mRNA was observed [76].
The signaling mechanisms involved in dietary regulation are not fully understood. The rapid increase of brush border $\mathrm{Na}^{+} / \mathrm{P}_{\mathrm{i}}$ cotransport was not blocked by cycloheximide, which suggests that de novo synthesis of $\mathrm{Na}^{+} / \mathrm{P}_{\mathrm{i}}$ cotransporters might not be necessary [73]. Yet, so far, there is no clear evidence for the existence of an intracellular, subapical pool of $\mathrm{Na}^{+} / \mathrm{P}_{\mathrm{i}}$ cotransporters that could explain the rapid adaptive phenomenon. Based on the observation that the fall in the serum level of $\mathrm{P}_{\mathrm{i}}$ after ingestion of a low $\mathrm{P}_{\mathrm{i}}$ diet precedes up-regulation of $\mathrm{Na} / \mathrm{Pi}$ cotransport [73], one might hypothesize the existence of one or more sensing mechanism(s) for $P_{i}$ that eventually may be located in the proximal tubular cells.

Renal excretion of $P_{i}$ decreases after ingestion of a diet rich in $\mathrm{P}_{\mathrm{i}}$ due to a reduction of apical $\mathrm{Na}^{+} / \mathrm{P}_{\mathrm{i}}$ cotransporter abundance. High $P_{i}$ diet induces internalization of both $\mathrm{NaPi}-1 \mathrm{la}$ and NaPi-llc, yet by distinct mechanisms. Whereas the amount of NaPi-lla in BBMV's was decreased after $2 \mathrm{~h}$, reduction of NaPi-llc was detectable only after $4 \mathrm{~h}$. As found for the PTH action, internalized NaPi-lla (by high $\mathrm{P}_{\mathrm{i}}$ diet) is routed to the lysosomes, whereas NaPi-llc is redistributed from the BBMV to a subapical compartment and does not undergo lysosomal degradation $[59,71,101]$.

Acute regulation of renal $P_{i}$ excretion has recently been investigated after application of a $\mathrm{P}_{\mathrm{i}}$ bolus directly into the duodenum of rats [13]. This maneuver elicited an increase of renal excretion of $P_{i}$ already within $15 \mathrm{~min}$. It is noteworthy that this response preceded changes in the plasma $\mathrm{P}_{\mathrm{i}}$, was independent of PTH and the phosphatonins FGF-23 and sFRP-4 and was not observed in animals with denervated kidneys. These data suggest that renal $P_{i}$ excretion may be part of an intestinal-renal axis that may include a novel (humoral) factor originating from the duodenal mucosa.

\section{Steroid hormones}

The influence of steroid hormones on renal $\mathrm{Na}^{+} / \mathrm{P}_{\mathrm{i}}$ cotransporters has been studied under chronic conditions. Although chronically administered, steroids could act via genomic mechanisms, nongenomic effects cannot be excluded. Furthermore, it has to be considered that other factors may be involved in the action of a particular steroid.

Glucocorticoids In addition to other effects in proximal tubules, such as stimulation of the rate of gluconeogenesis, glucocorticoids are also involved in the regulation of the renal handling of $P_{i}[36,39,108]$. In kidneys from rats that were treated chronically with dexamethasone, the amount of NaPi-lla protein and mRNA was decreased, in agreement with increased excretion of $P_{i}$ [72]. Furthermore, an inverse correlation between $\mathrm{Na}^{+} / \mathrm{P}_{\mathrm{i}}$-cotransport in BBMV's and glucosylceramide and sphingolipid content was reported in 
these studies. It remains to be determined if glucocorticoids may affect, besides NaPi-lla, other apical $\mathrm{Na}^{+} / \mathrm{P}_{i}$ cotransporters as well.

Estrogen Chronic treatment of ovarectomized rats with estrogen results in hypophosphatemia and hyperphosphaturia. Renal wasting of $\mathrm{P}_{\mathrm{i}}$ observed under these experimental conditions has been explained by reduced $\mathrm{Na}^{+} / \mathrm{P}_{i}$ cotransport in BBMV's due to a decrease of NaPi-lla abundance [8, 37]. Moreover, estrogen treatment was shown to decrease the abundance of NaPi-lla mRNA, whereas NaPi-llc mRNA was unaffected. It remains to be determined if the reported effect of estrogen on NaPi-lla is a direct or indirect one. Although the effect on NaPi-lla was reported to be independent of PTH [37], the reduction in NaPi-lla abundance could result from an indirect action of estrogen on dopamine receptors and/or the metabolism of dopamine in proximal tubules [68].

1,25(OH)2-Vitamin D3 (VitD3) Although the profound effects of VitD3 on the metabolisms and homeostasis of calcium and phosphate are well described [20, 108], conflicting results about direct effects of VitD3 on $\mathrm{P}_{\mathrm{i}}$ reabsorption in proximal tubules have been reported.

In thyroparathyroidectomized (TPTX) rats, chronic administration of VitD3 was reported to inhibit $\mathrm{P}_{\mathrm{i}}$ reabsorption in proximal tubules [82]. Although interference by PTH was excluded in this study, more recent data suggest that VitD3 action on renal $\mathrm{P}_{\mathrm{i}}$ handling could be indirectly, involving altered serum levels of phosphatonins [109]. For example, in intact rats, repeated injections of VitD3 resulted in an increase of serum levels of FGF-23 [106]. Furthermore, FGF-23 impairs the renal metabolism of VitD3 by suppressing the expression of 25 -hydroxyvitamin D $1 \alpha$ hydroxylase mRNA and by stimulation of the expression of 25-hydroxyvitamin D-24 hydroxylase mRNA [88, 107].

A VitD3 responsive element has been identified in the promoter region of the human NaPi-lla gene, suggesting that regulation of renal $\mathrm{P}_{\mathrm{i}}$ reabsorption by VitD3 may occur at the transcriptional level [114]. However, in VitD3 receptor and 1, $\alpha-\mathrm{OHase}^{-/-}$mice, the abundance of the $\mathrm{NaPi}-1$ la protein in BBMV was reported to be similar as the one of wild-type mice [24, 100], which indicates that at least in mice, the NaPi-lla abundance may not be controlled by VitD3 dependent transcriptional mechanisms.

\section{Changes in renal $P_{i}$ excretion not related to alterations of $\mathrm{Na}^{+} / \mathbf{P}_{\mathbf{i}}$ cotransporter abundance.}

Apart from the hormonal and metabolic settings that result in a change of the abundance of $\mathrm{Na}^{+} / \mathrm{P}_{\mathrm{i}}$ cotransporters as discussed above, a few observations indicate that altered renal Pi excretion can occur also without parallel changes of the amount of apical $\mathrm{Na} / \mathrm{Pi}$ cotransporters.

Potassium depletion

In rats depleted of potassium, $\mathrm{P}_{\mathrm{i}}$ excretion was increased and was in agreement with a decreased $\mathrm{Na}^{+} / \mathrm{P}_{\mathrm{i}}$ cotransport in isolated BBMV's. However, this change of $\mathrm{Na}^{+} / \mathrm{P}_{i}$ cotransport was not correlated with a reduced abundance of NaPi-lla, but instead by increased amounts of NaPi-lla. [131]. These contradictory findings were explained by an alteration of the lipid composition, (e.g., glucosylceramide), and altered fluidity of the brush border membrane. Similarly, altered rates of $\mathrm{Na}^{+} / \mathrm{P}_{i}$ cotransport occurring during aging and chronic adaptation to a dietary restriction of $\mathrm{P}_{\mathrm{i}}$ may also be explained partially by a change of membrane fluidity due to an altered ratio of lipids to cholesterol in the brush border membrane $[69,81]$.

\section{Metabolic acidosis}

Metabolic acidosis provokes an increase of $\mathrm{P}_{\mathrm{i}}$ excretion [11, 108]. Transcriptome analysis revealed that NaPi-llc mRNA is markedly down-regulated in mice after 2 days of metabolic acidosis, less pronounced down-regulation was observed for NaPi-lla mRNA [86]. In contrast, the abundance of both proteins was increased, consistent with higher $\mathrm{Na}^{+} / \mathrm{P}_{\mathrm{i}}$ cotransport in BBMV isolated from acidotic mice compared to control animals [87]. Increased urinary $\mathrm{P}_{\mathrm{i}}$ excretion was explained by a lower tubular $\mathrm{pH}$-value that decreases the transport rates of $\mathrm{NaPi}-\mathrm{lla} / \mathrm{c}$.

\section{Recovery after PTH treatment}

In rats injected with a single bolus of PTH, fractional excretion of $\mathrm{P}_{\mathrm{i}}$ was maximally increased after $40 \mathrm{~min}$ and recovered after 120 minutes. Whereas maximal excretion of $\mathrm{P}_{\mathrm{i}}$ correlated with a decrease of the abundance of NaPi-lla, the levels of NaPi-lla did not recover parallel to the recovery of $\mathrm{P}_{i}$ excretion [40]. These data indicate that the rate of recovery of the amounts of $\mathrm{Na}^{+} / \mathrm{P}_{\mathrm{i}}$ cotransporters after interventions that provoke their internalization is an important regulatory variable.

\section{Circadian rhythm}

Both serum concentration and renal excretion of $\mathrm{P}_{\mathrm{i}}$ undergo circadian variations [57]. In rats, fractional excretion of $\mathrm{P}_{\mathrm{i}}$ increased substantially between morning and late afternoon, yet, a change in the abundance of NaPi-lla was not detected [16]. Although part of this observation can be explained by an increase of serum $\mathrm{P}_{\mathrm{i}}$ during daytime, it remains to be 
shown if fluctuations of the amount of NaPi-llc and/or Pit-2 may contribute to the diurnal variations of $\mathrm{P}_{\mathrm{i}}$ excretion.

\section{Future directions - open questions}

Other (Na)/Pi (co)transporters? Although several $\mathrm{Na}^{+} / \mathrm{P}_{\mathrm{i}}$ cotransporters have been localized at the brush border membrane of proximal tubule cells, it is still possible that additional cotransporters may be involved in $\mathrm{P}_{\mathrm{i}}$ reabsorption along PT's. If so, it will be of interest to elucidate the relative contribution of each transporter to renal $P_{i}$ reabsorption in different species. Moreover, the often postulated handling of tubular $\mathrm{P}_{\mathrm{i}}$ in distal nephron segments remains to be clarified. Another long-standing open question is the molecular identity of the basolateral exit step of $\mathrm{P}_{\mathrm{i}}$.

Other phosphaturic factors? Recent investigations have added new members to the list of the factors that regulate $P_{i}$ reabsorption. In the light of a systemic control of renal $\mathrm{P}_{\mathrm{i}}$ handling by different axis (bone-kidney, intestine-kidney and eventually others) it is likely that more factors are about to come under the spotlight. Furthermore, the possibility of (a) $\mathrm{P}_{\mathrm{i}}$ sensing mechanism $(\mathrm{s})\left(\mathrm{P}_{\mathrm{i}}\right.$ sensor?) remains unanswered.

Control of apical abundance? Although current data suggest that phosphorylation reactions are involved in the control of the apical abundance of $\mathrm{Na}^{+} / \mathrm{P}_{i}$ cotransporters, e.g. by PTH, the signaling cascades of the diverse hormones (including the phosphatonins) that control their apical abundance remain to be elucidated. Moreover, the cellular mechanisms involved in the rapid adaptive responses to altered $\mathrm{P}_{\mathrm{i}}$ diets need further investigation.

Trafficking of $\mathrm{Na}^{+} / \mathrm{P}_{i}$ cotransporters Related to the intracellular trafficking of $\mathrm{Na} / \mathrm{Pi}$ cotransporters the following questions remain unanswered:

-How are $\mathrm{Na}^{+} / \mathrm{P}_{\mathrm{i}}$ cotransporters sorted to the apical membrane?

-Which mechanisms are involved in the routing of $\mathrm{Na}^{+} / \mathrm{P}_{\mathrm{i}}$ cotransporters (specifically NaPi-lla) from the subapical compartment to the lysosomes?

Acknowledgments Work in the authors' laboratories was supported by the Swiss National Science Foundation (SNF), the European Union (EuReGene), the Hartmann Müller Foundation, the Gebert Rüf Foundation, and Transregio SFB 11-Konstanz-Zürich.

\section{References}

1. Abraham MI, Woods RE, Breedlove DK, Kempson SA (1992) Renal adaptation to low phosphate diet in diabetic rats. Am J Physiol 262:F731-F736
2. Bacic D, Capuano P, Baum M, Zhang J, Stange G, Biber J, Kaissling B, Moe OW, Wagner CA, Murer H (2005) Activation of dopamine D1-like receptors induces acute internalization of the renal $\mathrm{Na} /$ phosphate cotransporter NaPi-lla in mouse kidney and OK cells. Am J Physiol 288:F740-F747

3. Bacic D, Hernando N, Traebert M, Lederer E, Völkl H, Biber J, Kaissling B, Murer H (2001) Regulation of the renal type lla Na/ Pi cotransporter by cGMP. Pflügers Arch 443:306-313

4. Bacic D, LeHir M, Biber J, Kaissling B, Murer H, Wagner CA (2006) The renal Na/phosphate cotransporter NaPi-lla is internalized via the receptor mediated endocytic route in response to parathyroid hormone. Kidney Int 69:495-503

5. Bacic D, Schulz N, Biber J, Kaislling B, Murer H, Wagner CA (2003) Involvement of the MAPK-kinase pathway in the PTHmediated regulation of the proximal tubule type 1la $\mathrm{Na} / \mathrm{Pi}$ cotransporter in mouse kidney. Pflügers Arch 446:52-60

6. Baum M, Schiavi S, Dwarakanath V, Quigley R (2005) Effect of fibroblast growth factor-23 on phosphate transport in proximal tubules. Kidney Int 68:1148-1153

7. Beck L, Karaplis AC, Amizuka N, Hewson AS, Ozawa H, Tenenhouse HS (1998) Targeted inactivation of Npt2 in mice leads to severe renal phosphate wasting, hypercalcuria, and skeletal abnormalities. Proc Natl Acad Sci (USA) 95:5372-5377

8. Beers KW, Thompson MA, Chini EN, Dousa TP (1996) betaEstradiol inhibits Na-Pi cotransport across renal brush border membranes from ovarectomized rats. Biochem Biophys Res Commun 221:442-445

9. Bergwitz C, Roslin NM, Tieder M, Loredo-Osti JC, Bastepe M, Abu-Zahra H, Frappier D, Burkett K, Carpenter TO, Anderson D, Garabedian M, Sermet I, Fujiwara TM, Morgan K, Tenenhouse HS, Juppner H (2005) SLC34A3 mutations in patients with hereditary hypophosphatemic rickets with hypercalcuria predict a key role for the sodium-phosphate cotransporter NaPi-llc in maintaining phosphate homeostasis. Am J Hum Genet 78:179 192

10. Berndt TJ, Bielesz B, Craig TA, Tebben PJ, Bacic D, Wagner CA, O’Brien S, Schiavi S, Biber J, Murer H, Kumar R (2006) Secreted frizzled-related protein 4 reduces sodium-phopshate cotransporter abundance and acvtivity in proximal tubule cells. Pflügers Arch 451:579-587

11. Berndt TJ, Knox FG (1992) Renal regulation of phosphate excretion. In: Seldin DW, Giebisch GH (eds) The Kidney, 2nd edn. Williams \& Wilkins, Philadelphia, Lippincott, pp 2511-2532

12. Berndt T, Kumar R (2007) Phosphatonins and the regulation of phosphate homeostasis. Annu Rev Physiol 69:341-359

13. Berndt T, Thomas LF, Craig TA, Sommer S, Li X, Bergstrahl EJ, Kumar R (2007) Evidence for a signaling axis by which intestinal phosphate rapidly modulates renal phosphate reabsorption. Proc Natl Acad Sci (USA) 104:11085-11090

14. Bevington A, Kemp GJ, Graham R, Russell G (1992) Phosphatesensitive enzymes: A possible molecular basis for cellular disorders of phosphate metabolism. Clin Chem Enzym Comms 4:235-257

15. Biber J, Gisler S, Hernando N, Murer H (2005) Protein/protein interactions (PDZ) in proximal tubules. J Membrane Biol 203: $111-118$

16. Bielesz B, Bacic D, Honegger K, Biber J, Murer H, Wagner CA (2006) Unchanged expression of the sodium-dependent phosphate cotransporter NaPi-lla despite diurnal changes in renal phosphate excretion. Pflügers Arch 452:683-689

17. Bielesz B, Klaushofer K, Oberbauer R (2004) Renal phosphate loss in hereditary and acquired disorders of bone mineralization. Bone 35:1229-1239

18. Bottger P, Hede SE, Grunnet M, Hoyer B, Klaerke DA, Pederson L (2006) Characterization of transport mechanisms and determinants critical for Na-dependent Pi symport of the Pit-family paralogs, human Pit1 and Pit2. Am J Physiol 291:C1377-C1387 
19. Brautbar N, Walling MW, Coburn JW (1979) Interactions between vitamin $\mathrm{D}$ deficiency and phosphorous depletion in the rat. J Clin Invest 63:335-341

20. Brown A, Dusso A, Slatopolsky E (2000) Vitamin D. In: Seldin DW, Giebisch GH (eds) The Kidney, 3rd edn. Williams \& Wilkins, Philadelphia, Lippincott, pp 1047-1090

21. Busch AE, Schuster A, Waldegger S, Wagner CA, Zempel G, Broer S, Biber J, Murer H, Lang F (1996) Expression of a renal type 1 sodium/phosphate transporter $(\mathrm{NaPi}-1)$ induces a conductance in Xenopus oocytes permeable for organic and inorganic anions. Proc Natl Acad Sci (USA) 83:5347-5351

22. Capuano P, Bacic D, Roos M, Gisler SM, Stange G, Biber J, Kaissling B, Weinman EJ, Shenolikar S, Wagner CA, Murer H (2007) Defective coupling of apical PTH receptors to phospholipase $\mathrm{C}$ prevents internalization of the Na-phosphate cotransporter NaPi1la in NHERF1 deficient mice. Am J Physiol 292:C927-C934

23. Capuano P, Bacic D, Stange G, Hernando N, Kaissling B, Pal R, Kocher O, Biber J, Wagner CA, Murer H (2005) Expression and regulation of the renal $\mathrm{Na}$ /phosphate cotransporter $\mathrm{NaPi}$-lla in a mouse model deficient for the PDZ protein PDZK1. Pflügers Arch 499:392-402

24. Capuano P, Radanovic T, Wagner CA, Bacic D, Kato S, Uchiyama Y, St-Arnoud R, Murer H, Biber J (2005) Intestinal and renal adaptation to a low Pi diet of type Na-Pi cotransporters in vitamin $\mathrm{D}$ receptor and 1a-OHase deficient mice. Am J Physiol 288:C429-C434

25. Carpenter T, Ellis BK, Insogna KL, Philbrick WM, Sterpka J, Shimkets R (2005) Firbroblast growth factor 7: An inhibitor of phosphate transport derived from oncogenic osteomalacia-causing tumors. J Clin Endocrinol Metab 90:1012-1020

26. Caverzasio J, Bonhour JP (1985) Mechanism of rapid phosphate transport adaptation to a single low Pi meal in rat renal brush border membranes. Pflügers Arch 404:227-231

27. Chang Q, Hoefs S, van der Kemp AW, Topala CN, Bindels RJ, Hoenderop JG (2005) The beta-glucuronidase klotho hydrolyzes and activates the TRPV5 channel. Science 310:490-493

28. Christensen EI, Nielsen R (2007) Role of megalin and cubulin in renal physiology and pathophysiology. Rev Physiol Biochem Pharmacol 158:1-22

29. Collins JF, Ghishan FK (2004) The SLC20 family of proteins: dual functions as sodium-phosphate cotransporters and viral receptors. Pflügers Arch 447:647-652

30. Consortium TA (2000) Autosomal dominant hypophosphatemic rickets is associated with mutations in FGF23. Nat Genet 26:345-348

31. Cunningham R, Esmaili A, Brown E, Biswas RS, Murtazina R, Donowitz M, Dijkman HB, van der Vlag J, Hogema BM, De Jonge HR, Shenolikar S, Wade JB, Weinman EJ (2008) Urine electrolyte, mineral, and protein excretion in NHERF-2 and NHERF-1 null mice. Am J Physiol 294:F1001-F1007

32. Custer M, Lötscher M, Biber J, Murer H, Kaissling B (1994) Expression of $\mathrm{Na} / \mathrm{Pi}$ cotransport in rat kidney: Localization by RTPCR and immunohistochemistry. Am J Physiol 266:F767-F774

33. Custer M, Meier F, Schlatter E, Greer R, Garcia-Perez A, Biber J, Murer H (1993) Localization of NaPi-1, a NaPicotransporter in rabbit kidney proximal tubules. Pflügers Arch 424:203-209

34. Deliot N, Hernando N, Liu-Horst Z, Gisler SM, Capuano P, Wagner CA, Bacic D, O'Brien S, Biber J, Murer H (2005) Parathyroid hormone treatment induces dissociation of type lla $\mathrm{Na}-\mathrm{Pi}$ cotransporter/ $\mathrm{Na} / \mathrm{H}$ exchanger regulatory factor-1 complexes. Am J Physiol 289:C159-C167

35. Dobbie H, Unwin RJ, Faria NJR, Shirley DG (2008) Matrix extracellular phosphoglycoprotein causes phosphaturia in rats by inhibiting tubular phosphate reabsorption. Nephrol Dial Transplant 23:730-733
36. Dousa TP, Kempson SA (1982) Regulation of renal brush border membrane transport of phosphate. Miner Electrolyte Metab $7: 113-121$

37. Faroqui S, Levi M, Soleimani M, Amlal H (2008) Estrogen downregulates the expression of proximal tubule NaPi-lla and causes phosphate wasting and hypophosphatemia. Kidney Int 73:1141-1150

38. Forster IC, Köhler K, Biber J, Murer H (2002) Forging the link between structure and function of electrogenic cotransporters: the renal type lla $\mathrm{Na} / \mathrm{Pi}$ cotransporter as a case study. Prog Biophys Mol Biol 80:69-108

39. Friedlander G (1998) Autocrine/paracrine control of renal phosphate transport. Kidney Int Suppl 65:S18-S23

40. Friedlaender MM, Wald H, Dranitzky-Elhalel M, Levi M, Popovtzer MM (2004) Recovery of renal tubule phosphate reabsorption despite reduced levels of sodium-phosphate transporter. Europ J Endocrin 151:797-801

41. Gensure RC, Gardella TJ, Jüppner H (2005) Parathyroid hormone and parathyroid hormone related peptide, and their receptors. Biochim Biophys Acta 328:666-678

42. Gisler SM, Kittanakom S, Fuster D, Wong V, Bertic M, Radanovic T, Hall RA, Murer H, Biber J, Markovich D, Moe OW, Stagliar I (2008) Monitoring protein-protein interactions between the mammalian renal epithelial integral membrane proteins and their PDZ interacting partners using the type II split ubiquitin membrane yeast two-hybrid system. Molec Cell Proteomics713621377

43. Gisler SM, Pribanic S, Bacic D, Forrer P, Sabourin LA, Tsuji A, Zhao Z, Manser E, Biber J, Murer H (2003) PDZK1: A major scaffolder in brush borders of proximal tubular cells. Kidney Int 64:1733-1745

44. Gisler SM, Stagliar I, Traebert M, Bacic D, Biber J, Murer H (2001) Interaction of the type lla $\mathrm{Na} / \mathrm{Pi}$-cotransporter with PDZ proteins. J Biol Chem 276:9206-9213

45. Gmaj P, Murer H (1986) Cellular mechanisms of inorganic phosphate transport in kidney. Physiol Rev 66:36-70

46. Guntupalli J, Eby B, Lau K (1982) Mechanism for the phosphaturia of $\mathrm{NH}_{4} \mathrm{Cl}$ : dependence on acidemia but not on diet $\mathrm{PO}_{4}$ or PTH. Am J Physiol 242:F552-F560

47. Haggie PM, Stanton BA, Verkman AS (2003) Increased diffusional mobility of CFTR at the plasma membrane after deletion of its C-terminus PDZ binding motif. J Biol Chem 279:5494-5500

48. Hammond TG, Yusufi AN, Knox FG, Dousa TP (1985) Administration of atrial natriuretic factor inhibits sodium-coupled transport in proximal tubules. J Clin Invest 75:1983-1989

49. Hernando N, Deliot N, Gisler SM, Lederer E, Weinman EJ, Biber J, Murer H (2002) PDZ domain interactions and apical expression of type lla Na/Pi-cotransporters. Proc Natl Acad Sci (USA) 99:11957-11692

50. Hernando N, Forgo J, Biber J, Murer H (2000) PTH-induced downregulation of the type lla $\mathrm{Na} / \mathrm{Pi}$-cotransporter is independent of known endocytic motifs. J Am Soc Nephrol 11:1961-1968

51. Hruska KA, Methew S, Lund R, Qui P, Pratt R (2008) Hyperphosphatemia of chronic diseases. Kidney Int 74:148-157

52. Hu MC, Zhang J, Shi M, Rosenblatt K, Baum M, Kuro OM, Moe OW (2006) Klotho is a phosphaturic hormone: in vivo evidence. J Am Soc Nephrol 17:105a

53. Imura A, Iwano A, Tohyama O, Tsuji Y, Nozaki K, Hashimoto N, Fujimori T, Nabeshima Y (2004) Secreted Klotho protein in sera and CSF: implication for post-translational cleavage in release of Klotho protein from cell membrane. FEBS Lett 565: 143-147

54. Ito $\mathrm{M}$, Iidawa $\mathrm{S}$, Izuka $\mathrm{M}$, Haito $\mathrm{S}$, Segawa $\mathrm{H}$, Kuwahata $\mathrm{M}$, Ohkido I, Ohno H, Miyamoto KI (2004) Interaction of a farnesylated protein with renal type lla $\mathrm{Na} / \mathrm{Pi}$ cotransporter in 
response to parathyroid hormone and dietary phosphate. Biochem J 377:607-616

55. Jüppner H (2007) Novel regulators of phosphate homeostasis and bone metabolism. Therap Apher Dial 11:S3-S22

56. Karim-Jimenez Z, Hernando N, Biber J, Murer H (2000) A dibasic motif involved in parathyroid hormone-induced downregulation of the type lla NaPi cotransporter. Proc Natl Acad Sci (USA) 97:12896-12901

57. Kemp GJ, Blumsohn A, Morris BW (1992) Circadian changes in plasma phosphate concentration, urinary phosphate excretion, and cellular phosphate shifts. Clin Chem 38:400-402

58. Kempson SA, Lötscher M, Kaissling B, Biber J, Murer H, Levi M (1995) Parathyroid hormone action on phosphate transporter mRNA and protein in rat renal proximal tubules. Am J Physiol 268:F784-F791

59. Keusch I, Traebert M, Lötscher M, Kaislling B, Murer H, Biber J (1998) Parathyroid hormone and dietary phosphate provoke lysosomal routing of the proximal tubular $\mathrm{Na} / \mathrm{Pi}$-cotransporter type 11. Kidney Int 54:1224-1232

60. Kido S, Miyamoto K, Mizobuchi H, Taketani Y, Ohkido I, Ogawa N, Kaneko Y, Harashima S, Takeda E (1999) Identification of regulatory sequences and binding proteins in the type 11 sodium/phosphate cotransporter NPT2 gene responsive to dietary phosphate. J Biol Chem 274:28256-28263

61. Kittler JT, Rostaing P, Schiavo G, Fritschy JM, Olsen R, Triller A, Moss SJ (2001) The subcellular distribution of GABARAP and its ability to interact with NSF suggest a role for this protein in the intracellular transport of GABA(A) receptors. Mol Cell Neurosci $18: 13-25$

62. Knochel JP (2000) Clinical and physiologic phosphate disturbances. In: Seldin DW, Giebisch GH (eds) The Kidney, 3rd edn. Williams \& Wilkins, Philadelphia, Lippincott, pp 1905-1934

63. Köhler K, Forster IC, Lambert G, Biber J, Murer H (2000) The functional unit of the renal type $\mathrm{IIa} \mathrm{Na}{ }^{+} / \mathrm{P}_{\mathrm{i}}$ cotransporter is a monomer. J Biol Chem 275:26113-26120

64. Kreusser WJ, Descoeudres C, Oda Y, Massry SG, Kurokawa K (1980) Effect of phosphate depletion on renal gluconeogenesis. Miner Electrolyte Metab 3:312-323

65. Kuro OM (2006) Klotho as a regulator of fibroblast growth factor signaling and phosphate/calcium metabolism. Curr Opin Nephrol Hypertens 15:437-441

66. Kurosu H, Ogawa Y, Miyoshi M, Yamamoto M, Nandi A, Rosenblatt KP, Baum MG, Schiavi S, Hu M-C, Moe OW, Kuro-o M (2006) Regulation of fibroblast growth factor-23 signaling by klotho. J Biol Chem 281:6120-6123

67. Lederer ED, Sohi SS, McLeish KR (2000) Parathyroid hormone stimulates extracellular signal-regulated kinase (ERK) activity through two independent signal transduction pathways: role of ERK in sodium-phosphate cotransport. J Am Soc Nephrol 11:222-231

68. Lee SH, Mouradian MM (1999) Up regulation of D1A dopamine receptor gene transcription by estrogen. Mol Cell Endocrinol 156:151-157

69. Levi M, Baird BM, Wilson PV (1990) Cholesterol modulates rat renal brush border membrane phosphate transport. J Clin Invest $85: 231-237$

70. Levi M, Blaine J, Breusegem S, Takahashi H, Sorribas V, Barry N (2006) Renal phosphate-wasting disorders. Adv Chron Kidney Dis 13:155-165

71. Levi M, Kempson SA, Lötscher M, Biber J, Murer H (1996) Molecular regulation of renal phosphate transport. J Membrane Biol 154:1-9

72. Levi M, Shayman JA, Abe A, Gross SK, McCluer RH, Biber J, Murer H, Lötscher M, Cronin RE (1995) Dexamethasone modulates rat renal brush border membrane phosphate transport- er mRNA and protein abundance and glycoshingolipid composition. J Clin Invest 96:207-216

73. Levine BS, Ho LD, Pasiecznik K, Coburn JW (1986) Renal adaptation to phosphorous deprivation: characterization of early events. J Bone Miner Res 1:33-40

74. Liu S, Quarles LD (2007) How fibroblast growth factor 23 works. J Am Soc Nephrol 18:1637-1647

75. Lorenz-Depiereux B, Benet-Pages A, Eckstein G, TenenbaumRakover Y, Wagenstaller J, Tiosamo D, Gershoni-Baruch R, Albers N, Lichtner P, Schnabel D, Hochberg Z, Strom TM (2006) Hereditary hypophosphatemic rickets with hypercalcuria is caused by mutations in the sodium-phosphate cotransporter gene SLC34A3. Am J Hum Genet 78:193-201

76. Madjdpour C, Bacic D, Kaissling B, Murer H, Biber J (2004) Segment specific expression of sodium-phosphate cotransporters $\mathrm{NaPi}$ lla and -llc and interacting proteins in mouse renal proximal tubules. Pflügers Arch 448:402-410

77. Mahon MJ, Cole JA, Lederer ED, Segre GV (2003) Na/H exchanger regulatory factor 1 mediates inhibition of phosphate transport by parathyroid hormone and second messengers by acting at multiple sites in opossum kidney cells. Mol Endocrinol 17:2355-2364

78. McWilliams RR, Breusegem SY, Brodsky KF, Kim E, Levi M, Doctor RB (2005) Shank2E binds NaPi cotransporter at the apical membrane of proximal tubule cells. Am J Physiol 289: C1042-C1051

79. Miyamoto K, Ito M, Tatsumi S, Kuwahata M, Segawa H (2007) New aspect of renal phosphate reabsorption: the type IIc sodiumdependent phosphate transporter. Am J Nephrol 27:503-515

80. Miyamoto KI, Segawa H, Ito M, Kuwahata M (2004) Physiological regulation of renal sodium-phosphate cotransporters. Japan J Physiol 54:83-102

81. Molitoris BA, Alfrey AC, Harris RA, Simon FR (1985) Renal apical membrane cholesterol and fluidity in regulation of phosphate transport. Am J Physiol 249:F12-F19

82. Mühlbauer RC, Bonjour JP, Fleisch H (1981) Tubular handling of Pi: localization of effects of 1,25(OH)2D3 and dietary Pi in TPTX rats. Am J Physiol 241:F123-F128

83. Murer H, Forster I, Biber J (2004) The sodium phosphate cotransporter family SLC34. Pflügers Arch 447:763-767

84. Murer H, Hernando N, Forster I, Biber J (2000) Proximal tubular phosphate reabsorption. Physiol Rev 80:1373-1409

85. Nabeshima Y (2002) Klotho: a fundamental regulator of aging. Ageing Res Rev 1:627-638

86. Nowik M, Lecca MR, Velic A, Rehrauer H, Brändli AW, Wagner CA (2008) Genome-wide gene expression profiling reveals renal genes regulated during metabolic acidosis. Physiol Genomics 32:322334

87. Nowik M, Picard N, Stange G, Capuano P, Tenenhouse HS, Biber J, Murer H (2008) Renal phosphaturia during metabolic acidosis revisited: Molecular mechanisms for decreased renal phosphate reabsorption. Pflügers Arch (in press). doi:10.1007/s00424-0080530-5

88. Perward F, Zhang MYH, Tenenhouse HS, Portale AA (2007) Fibroblast growth factor 23 impairs phosphorus and vitamin D metabolism in vivo and suppresses 25 -hydroxyvitamin D 1ahydroxylase expression in vitro. Am J Physiol 293:F1577-F1583

89. Pfister MF, Ruf I, Stange G, Ziegler U, Lederer E, Biber J, Murer H (1998) Parathyroid hormone leads to the lysosomal degradation of the renal type II Na ${ }^{+} / \mathrm{P}_{\mathrm{i}}$-cotransporter. Proc Natl Acad Sci (USA) 95:1909-1914

90. Picard N, Capuano P, Bacic D, Biber J, Murer H, Le Hir M, Kaissling B, Wagner C (2007) Differential regulation of renal $\mathrm{Na}$ /phosphate cotransporters $\mathrm{NaPi}-1 \mathrm{lla}$ and $\mathrm{NaPi}-1 \mathrm{lc}$ in response to parathyroid hormone (PTH). J Am Soc Nephrol 18:109A 
91. Quarles LD (2003) Evidence for a bone-kidney axis regulating phosphate homeostasis. J Clin Invest 112:642-646

92. Radanovic T, Gisler SM, Biber J, Murer H (2007) Topology of the type IIa $\mathrm{Na}^{+} / \mathrm{P}_{\mathrm{i}}$-cotransporter. J Membrane Biol 212:41-49

93. Ravera S, Virkki LV, Murer H, Forster IC (2007) Deciphering PiT transport kinetics and substrate specificity using electrophysiology and flux measurements. Am J Physiol 293:C606C620

94. Reining S, Gisler SM, Biber J, Murer H, Hernando N (2007) Association of NaPI-lla with the interacting proteins PDZK2 and Gabarap. J Am Soc Nephrol 18:123A

95. Rowe PS, de Zoysa PA, Dong R, Wang HR, White KE, Econs MJ, Oudet CL (2000) MEPE, a new gene expressed in bone marrow and tumors causing osteomalacia. Genomics 67:54-68

96. Rowe PS, Kumagai Y, Gutierrez G, Garrett IR, Blacher R, Rosen D, Cundy J, Navvab S, Chen D, Drezner MK, Quarles LD, Mundy GR (2004) MEPE has the properties of an osteoblastic phosphatonin and minhibin. Bone 34:303-319

97. Saito H, Maeda A, Ohtomo S, Hirata M, Kusano K, Kato S, Ogata E, Segawa H, Miyamoto K, Fukushima N (2005) Circulating FGF-23 is regulated by 1alpha, 25-dihydroxyvitamin D3 and phosphorus in vivo. J Biol Chem 280:2543-2549

98. Salaun C, Rodrigues P, Heard JM (2001) Transmembrane topology of Pit-2, a phosphate transporter-retrovirus receptor. J Virol 75:5584-5592

99. Segawa H, Kaneko I, Takahashi A, Kuwahata M, Ito M, Ohkido I, Tatsumi S, Miyamoto K (2002) Growth-related renal type $11 \mathrm{Na} / \mathrm{Pi}$ cotransporter. J Biol Chem 277:19665-19672

100. Segawa H, Kaneko I, Yamanaka S, Ito M, Kuwahata M, Inoue Y, Kato S, Miyamoto K (2004) Intestinal Na-Pi cotransporter adaptation to dietary $\mathrm{Pi}$ content in vitamin $\mathrm{D}$ receptor null mice. Am J Physiol 287:F39-F47

101. Segawa H, Yamanaka S, Ito M, Kuwahata M, Shono M, Yamamoto T, Miyamoto KI (2005) Internalization of renal type llc Na-Pi cotransporter in response to a high-phosphate diet. Am J Physiol 288:F587-F596

102. Segawa H, Yamanaka S, Ohno Y, Onitsuka A, Shiozawa K, Aranami F, Furutani J, Tomoe Y, Ito M, Kuwahata M, Imura A, Nabeshima Y, Miyamoto KI (2007) Correlation between hyperphosphatemia and type $11 \mathrm{Na}-\mathrm{Pi}$ cotransporter activity in klotho mice. Am J Physil 292:F769-F779

103. Segawa H, Yamanaka S, Onitsuka A, Tomoe Y, Kuwahata M, Ito M, Taketani Y, Miyamoto KI (2007) Parathyroid hormone-dependent endocytosis of renal type 1lc Na-Pi cotransporter. Am J Physiol 292: F395-F403

104. Shenolikar S, Voltz JW, Cunningham R, Weinman EJ (2004) Regulation of ion transport by the NHERF family of PDZ proteins. Physiology 19:48-54

105. Shenolikar S, Voltz JW, Minkoff CM, Wade J, Weinman EJ (2002) Targeted disruption of the mouse gene encoding a PDZ domain containing protein adaptor, NHERF-1, promotes Npt2 internalization and renal phosphate wasting. Proc Natl Acad Sci (USA) 99:11470-11475

106. Shimada T, Hasegawa $H$, Yamazaki $Y$, Muto $T$, Hino $R$, Takeuchi Y, Fujita T, Nakahara K, Fukumoto S, Yamashita T (2004) FGF-23 is a potent regulator of vitamin D metabolism and phosphate homeostasis. J Bone Miner Res 19:429-435

107. Shimada T, Kakitani M, Yamazaki Y, Hasegawa H, Takeuchi Y, Fujita T, Fukumoto S, Tomizuka K, Yamashita T (2004) Targeted ablation of FGF23 demonstrates an essential physiological role of FGF23 in phosphate and vitamin D metabolism. J Clin Invest 113:561-568

108. Silve C, Friedlander G (2000) Renal regulation of phosphate excretion. In: Seldin DW, Giebisch GH (eds) The Kidney, 3rd edn. Williams \& Wilkins, Philadelphia, Lippincott, pp 1885-1903
109. Sommer S, Berndt T, Craig T, Kumar R (2007) The phosphatonins and the regulation of phosphate transport and vitamin $\mathrm{D}$ metabolism. J Steroid Bioch Mole Biol 103:497-503

110. Spitzer A, Barac-Nieto M (2001) Ontogeny of renal phosphate transport and the process of growth. Pediatr Nephrol 16:763-771

111. Syal A, Schiavi S, Chakravarty S, Dwarakanath V, Quigley R, Baum M (2006) Fibroblast growth factor-23 increases mouse PGE2 production in vivo and in vitro. Am J Physiol 290:F450 F455

112. Szczepanska-Konkel M, Yusufi AN, VanScoy M, Webster SK, Dousa TP (1986) Phosphonocarboxylic acids as specific inhibitors of Na-dependent transport of phosphate across renal brush border membranes. J Biol Chem 261:6375-6383

113. Takeda E, Yamamoto H, Nashiki K, Sato T, Arai H, Taketani Y (2004) Inorganic phosphate homeostais and the role of dietary phosphorus. J Cell Mol Med 8:191-200

114. Taketani Y, Segawa H, Chikamori M, Morita K, Tanaka K, Kido S, Yamamoto $\mathrm{H}$, Iemori $\mathrm{Y}$, Tatsumi $\mathrm{S}$, Tsugawa $\mathrm{N}$, Okano $\mathrm{T}$, Kobayashi T, Miyamoto K, Takeda E (1998) Regulation of type renal Na-dpendent inorganic phosphate transporters by $1,25-$ dihydroxyvitamin D3. Identification of a vitamin D-responsive element in the human NaPi-3 gene. J Biol Chem 273:1457514581

115. Tenenhouse HS, Martel J, Gauthier C, Segawa H, Miyamoto K (2003) Differential effects of Npt2a gene ablation and X-linked Hyp mutation on renal expression of Npt2c. Am J Physiol 285: F1271-F1278

116. Tenenhouse HS, Roy S, Martel J, Gauthier C (1998) Differential expression, abundance, and regulation of Na-phosphate cotransporter genes in murine kidney. Am J Physiol 275:F527-F534

117. Tenenhouse HS, Sabbagh Y (2002) Novel phosphate-regulating genes in the pathogenesis of renal phosphate wasting disorders. Pflügers Arch 444:317-326

118. Tohyama O, Imura A, Iwano A, freund JN, Henrissat B, Fujimori T, Nabeshima YI (2004) Klotho is a novel beta-glucuronidase capable of hydrolyzing steroid beta-glucuronides. J Biol Chem 279:97779784

119. Traebert M, Volkl H, Biber J, Murer H, Kaislling B (2000) Luminal and contraluminal action of $1-34$ and 3-34 PTH peptides on renal type 1la Na/Pi-cotransporter. Am J Physiol 278:F792-F798

120. Tröhler U, Bonjour JP, Fleisch H (1976) Renal adaptation to dietary intake in intact and thyroparathyroidectomized rats. J Clin Invest 57:264-273

121. Ullrich KJ, Murer H (1982) Sulfate and phosphate transport in rat kidney proximal tubule. Philos Trans R Soc Lond B Biol Sci 299:549-558

122. Urakawa I, Yamazaki Y, Shimada T, Iijima K, Hasegawa H, Okawa K, Fujita T, Fukumoto S, Yamashita T (2007) Klotho converts canonical FGF receptor into a specific receptor for FGF23. Nature 444:770-774

123. Villa-Bellosta R, Barac-Nieto M, Breusegem SY, Barry NP, Levi M, Sorribas V (2008) Interactions of the growth-related, type llc renal sodium/phosphate cotransporter with PDZ proteins. Kidney Int 73:456-464

124. Virkki LV, Biber J, Murer H, Forster IC (2007) Phosphate transporters: a tale of two solute carrier families. Am J Physiol 293:F643-F654

125. Virkki LV, Forster IC, Biber J, Murer H (2005) Substrate interactions in the human type lla sodium-phosphate cotransporter (NaPi-1la). Am J Physiol 288:F969-F981

126. Wagner CA, Hernando N, Forster I, Biber J, Murer H (2008) Genetic defects in renal phosphate handling. In: Genetic diseases of the kidney, edited by Lifton RP, Somlo S, Giebisch G, Seldin DW, Elsevier, (in press). 
127. Weber TJ, Liu S, Indridason OS, Quarles LD (2003) Serum FGF23 levels in normal and disordered phosphorus homeostasis. J Bone Miner Res 18:1227-1234

128. Weinman EJ, Biswas RS, Peng Q, Shen L, Turner CL, E X, Steplock D, Shenolikar S, Cunningham R (2007) Parathyroid hormone inhibits renal phosphate transport by phosphorylation of serine 77 of sodium-hydrogen exchanger regulatory factor-1. J Clin Invest 117:3412-3420

129. Yamashita T, Konishi M, Miyake A, Inui K, Itoh N (2002) Fibroblast growth factor (FGF)-23 inhibits renal phosphate reabsorption by activation of the mitogen-activated protein kinase pathway. J Biol Chem 277:28265-28270

130. Yeaman C, Grindstaff KK, Hansen MD, Nelson WJ (1999) Cell polarity: versatile scaffolds keep things in place. Curr Biol 15: R515-R517

131. Zajicek HK, Wang H, Puttaparthi K, Halaihel N, Markovich D, Shayman J, Beliveau R, Wilson R, Rogers $\mathrm{T}$, Levi M (2001) Glycosphingolipids modulate renal phosphate transport in potassium deficiency. Kidney Int 60: 694-704 